\title{
Protein synthesis regulation by leucine
}

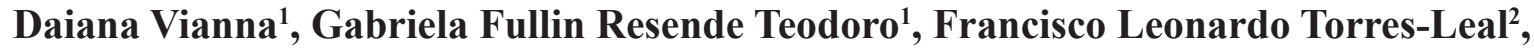 \\ Julio Tirapegui ${ }^{1,2, *}$
}

\author{
${ }^{1}$ Department of Food Science and Experimental Nutrition, Faculty of Pharmaceutical Sciences, University of São Paulo, \\ ${ }^{2}$ Department of Food Science and Experimental Nutrition, Faculty of Pharmaceutical Sciences, PRONUT, University of São Paulo.
}

\begin{abstract}
In vivo and in vitro studies have demonstrated that high protein diets affect both protein synthesis and regulation of several cellular processes. The role of amino acids as substrate for protein synthesis has been established in the literature. However, the mechanism by which these amino acids modulate transcription and regulate the mRNA translation via mTOR-dependent signaling pathway has yet to be fully determined. It has been verified that $\mathrm{mTOR}$ is a protein responsible for activating a cascade of biochemical intracellular events which result in the activation of the protein translation process. Of the aminoacids, leucine is the most effective in stimulating protein synthesis and reducing proteolysis. Therefore, it promotes a positive nitrogen balance, possibly by favoring the activation of this protein. This amino acid also directly and indirectly stimulates the synthesis and secretion of insulin, enhancing its anabolic cellular effects. Therefore, this review aimed to identify the role of leucine in protein synthesis modulation and to discuss the metabolic aspects related to this aminoacid.
\end{abstract}

Uniterms: Leucine. Protein synthesis. Transcription Factors. mTOR. Translation Protein.

Estudos in vivo e in vitro verificaram que dietas hiperprotéicas influenciam a síntese protéica e regulam vários processos celulares. O papel dos aminoácidos como substrato para a síntese de proteínas já está bem evidenciado na literatura, porém as formas como esses aminoácidos modulam a etapa da transcrição e regulam a tradução do RNAm, pela via de sinalização dependente da mTOR, ainda não estão totalmente esclarecidas. Tem-se verificado que a mTOR é uma proteína responsável por ativar uma cascata de eventos bioquímicos intracelulares que culminam na ativação do processo de tradução protéica. Dentre todos os aminoácidos, a leucina é a mais eficaz em estimular a síntese protéica, reduzir a proteólise e, portanto, favorecer o balanço nitrogenado positivo, possivelmente por favorecer a ativação desta proteína. Além disso, este aminoácido estimula direta e indiretamente a síntese e a secreção de insulina, e, assim, aumenta as propriedades anabólicas celulares. Nesse sentido, a presente revisão tem como objetivo identificar o papel da leucina na modulação da síntese protéica e abordar aspectos metabólicos relacionados a este aminoácido.

Unitermos: Leucina. Síntese protéica. Fator de transcrição. mTOR. Tradução de proteínas.

\section{INTRODUCTION}

Protein synthesis in tissue is rapidly stimulated after nutrient consumption. Insulin and aminoacids stimulate protein anabolism, acting in a posterior step of gene transcription, i.e., on protein translation. However, the mechanism by which the aminoacids stimulate protein translation has yet to be fully determined (Proud, 2002).

\footnotetext{
*Correspondence: J. Tirapegui. Departamento de Alimentos e Nutrição Experimental, Faculdade de Ciências Farmacêuticas - USP. Av. Prof. Lineu Prestes, n. 580 - Bloco 14 - 05508-900 - São Paulo - SP, Brazil. E-mail: tirapegu@usp.br
}

Some studies have verified that high-protein diets stimulate protein synthesis. Some of the benefits promoted by this diet on body composition can be attributed to high consumption of branched-chain aminoacids (BCAA), which include the aminoacids leucine, valine and isoleucine (Donato et al., 2004; Layman, Walker, 2006; Katsanos et al., 2006). According to this hypothesis, high protein consumption not only increases the availability of substrates (aminoacids) for protein synthesis, but also stimulates anabolic processes observed after high protein consumption (Campos et al., 1999).

Leucine has been shown to modulate the rate of 
protein synthesis, particularly by stimulating the activity of proteins involved in the translation process, which is critical for cells to control protein synthesis (Anthony et al., 2001; Lynch, Hutson, Patson, 2002a; Crozier et al., 2005; Garlick, 2005; Kimball, Jefferson, 2006). This modulation may involve the activation of specific intracellular pathways involved in protein synthesis, including activation of the mammalian target of rapamycin (mTOR) pathway.

It has been observed that $m$ Tor responds immediately to any modification in aminoacid or energy consumption (Bruhat et al., 2002; Asnaghi et al., 2004). When aminoacid storage, particularly leucine, is elevated, mTOR interacts with other proteins to form protein complexes in order to phosphorylate their key-components, which are in turn responsible for translating mRNA into proteins. These complexes include the binding of eukaryotic initiation factor $4 \mathrm{E}$ to the cap region; the activation via phosphorylation of $70 \mathrm{kDa}$-ribossomal protein S6 kinase-1 (S6K1); and the elongation of eIF2 factor (Fingar, Blenis, 2004; Hay, 2004). On the other hand, depletion of intracellular aminoacid pool, or their removal from the extracellular media, inhibits mTOR resulting in the suppression of protein synthesis (Maloney, 2005). However, how leucine modulates these molecular events has not been fully elucidated.

Considering these aspects, this literature review aimed to identify the role of leucine in protein synthesis modulation and to discuss the metabolic aspects related to this aminoacid.

\section{LEUCINE METABOLISM}

Unlike other aminoacids that are degraded in the liver, BCAA (leucine, isoleucine and valine) as well as alanine, glutamate and aspartate are oxidized in skeletal muscle (Rossi, 2005). Of the 3 BCAAs, leucine presents a remarkable and higher oxidation rate compared to isoleucine and valine. Enzymes involved in leucine catabolism include mitochondrial and cytosolic branchedchain aminoacid aminotransferases (BCAT) and the enzymatic complex branched-chain ketoacid dehydrogenase (BCKDH) (Shimomura et al., 2004). From the reaction catalyzed by BCAT, which is reversible, the aminoacid is transamined and converted into its respective ketoacid, $\alpha$-keto-iso-caproate (KIC). Simultaneous to this reaction, the conversion of $\alpha$-ketoglutarate - a nitrogen acceptor derived from BCAA - into glutamate also takes place. This reaction is able to promote synthesis of other aminoacids, such as alanine and glutamine. After the reaction catalyzed by BCAT, the ketoacid suffers oxidative decarboxylation, which is an irreversible reaction mediated by BCKDH.
This enzymatic complex is found on the inner surface of the mitochondrial membrane. From this reaction, KIC is converted into isovaleryl-CoA which is oxidized by two different dehydrogenases, generating acetyl-CoA and acetoacetate as final products (Anthony et al., 2001).

In mammals, the BCKDH complex presents three enzymes: $\alpha$-ketoacid decarboxylase (E1), constituted by the subunits $2 \alpha$ and $2 \beta$, dihydrolipoyl transacetylase (E2), and dihydrolipoyl dehydrogenase (E3) (Harris et al., 1986). In tissues, the activity of this complex is regulated by a cycle of phosphorylation and dephosphorylation catalyzed by a specific kinase and a phosphatase. The phosphorylation state is primarily controlled by the activity of BCKDH kinase (BCKDHK). This enzyme promotes the inactivation of $\mathrm{BCKDH}$, through phosphorylation of unit E1 $\alpha$. The activation of the BCKDH complex can be swiftly achieved by inhibition of BCKDHK promoted by leucine's ketoacid and its structural analogues, including octanoate, $\alpha$-cloroisocaproate and clorofibric acid. The dephosphorylation process is mediated by $\mathrm{BCKDH}$ phosphatase (BCKDHP) which is responsible for activating the BCKDH complex and dephosphorylating the sub-unit E1 $\alpha$ (Anthony et al., 2001; Shimomura, Harris, 2006). The activity of this complex is influenced by hormones, diabetes, exercise, fasting, acidosis or protein-restricted diets, depending on the tissue (Araujo et al., 2006).

\section{THE LEUCINE PARADOX}

Unbalanced diets containing high leucine concentrations usually result in a reduction in body valine and isoleucine levels. This phenomenon is known as the "leucine paradox". This fact may be partly explained by the activation of BCAA oxidation, via complex BCKDH, leading to negative $\mathrm{BCKDHK}$ regulation, concomitant to an inhibitory effect of KIC on this enzyme. These two factors promote $\mathrm{BCKDH}$ activation, depleting the ketoacids from other aminoacids, most notably valine and isoleucine. On the other hand, it should be noted that leucine administration also stimulates protein synthesis and inhibits protein degradation. Both situations indirectly affect the levels of valine and isoleucine (Shimomura, Harris, 2006).

\section{THE INFLUENCE OF LEUCINE ON THE PRO- TEIN SYNTHESIS MECHANISM}

The anabolic effect of leucine on protein synthesis is of great nutritional interest for attenuation of loss of lean body mass, which occurs in catabolic states and in specific physiological conditions such as aging (Stipanuk, 2007). Many studies have been conducted to clarify this effect, 


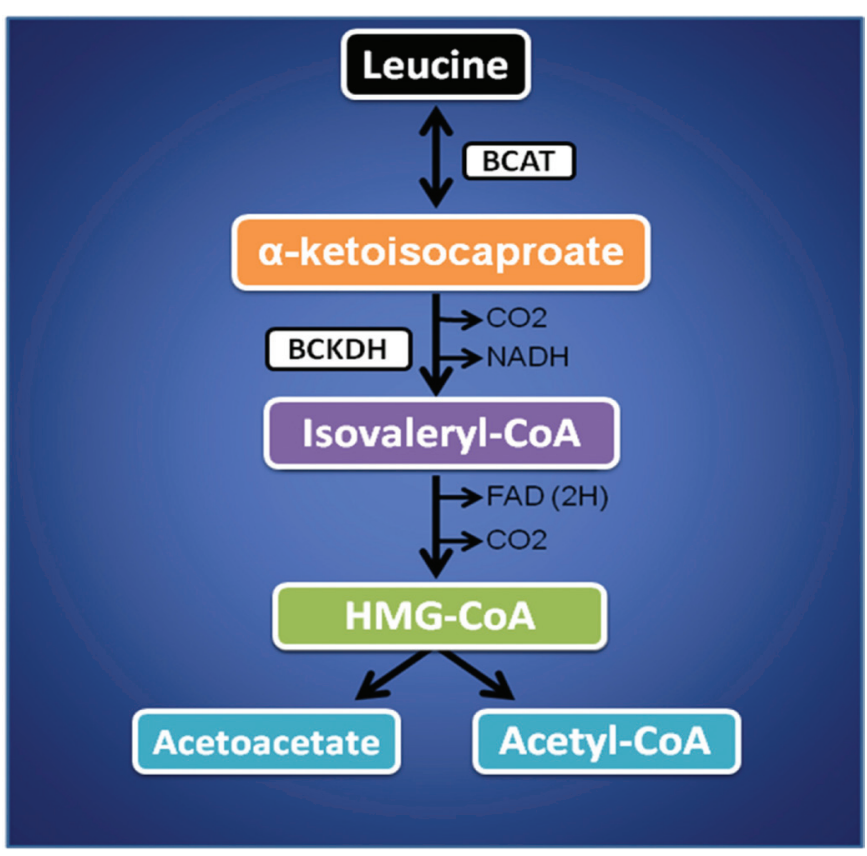

FIGURE 1 - Leucine metabolism. Adapted from Smith, Marks and Liberman (2005).

as it was previously observed that leucine, besides serving as a direct substrate for protein synthesis, also contributes toward stimulating this process, exerting a positive effect on the phosphorylating proteins involved in the translation initiation process of mRNA (Rogero, Tirapegui, 2008).

Leucine exerts an effect on the short-term regulation at the level of translation in protein synthesis. This effect is synergistic with insulin, which is an anabolic hormone with a critical role of maintaining muscle protein synthesis. However, insulin alone is not able to completely restore the rate of protein synthesis in muscle during the post-absorptive state, requiring protein or aminoacid consumption to fully restore the anabolic effect (Rogero, Tirapegui, 2008; Bolster, Kimbal, Jefferson, 2003).

Leucine also plays a role as an insulin secretagogue. Oral leucine administration results in a slight transient increase in serum insulin levels, which also stimulates protein synthesis induced by this aminoacid (Rogero, Tirapegui, 2008; Bolster, Kimbal, Jefferson, 2003). Although basal insulin levels are important to potentialize the effect mediated by leucine (Stipanuk, 2007), this aminoacid also acts as a nutrient signal which regulates protein synthesis in adipocytes, as well as in other cells, through an insulinindependent mechanisms (Lynch et al., 2002). This result may be a consequence of a direct (leucine action) or indirect (leucine metabolite, such as KIC) effect on tissue, as this effect has been already observed in isolated cells. Additionally, these effects were also seen in in vitro and in vivo studies with infusion of norleucine, an analogue com- pound of leucine that does not stimulate insulin secretion nor is incorporated into the protein structure (Anthony et al., 2001; Lynch et al., 2000, 2002b).

There are specific pathways favoring protein synthesis, as well as cell growth and proliferation, such as the pathway mediated by mTOR protein. This pathway is stimulated by mitogens, including insulin and BCAA but particularly leucine (Cota et al., 2006). However, the mechanism underlying this effect has yet to be elucidated.

The insulin signaling pathway initiates with insulin binding to its receptor. Once activated, the insulin receptor phosphorylates many protein substrates for tyrosine. Some of these substrates belong to the insulin receptor substrate family, the IRS proteins (Zick, 2004; Gual, Le Marchnd-Brsutel, Tanti, 2005). Phosphorylation of IRS proteins for tyrosine creates recognition sites for a number of molecules such as the enzyme phosphatidylinosytol-3kinase (PI 3-K). There is a close association between this enzyme and insulin receptor substrate-1 (IRS-1) (Kim et al., 1999). The protein target of this enzyme is Akt/PKB, which is responsible for regulating glucose transport. In peripheral tissues, the phosphorylation of Akt/PKB promotes a number of effects such as translocation of glucose transporter type 4 (GLUT-4) to plasma membrane, regulation of protein synthesis, glycogen metabolism and cell cycle progression (Georgakis, Younes, 2006).

Leucine also stimulates protein synthesis by modulating elements that are involved in the insulin signaling pathway translation via PI3-K (Figure 2). Therefore, this aminoacid inhibits insulin signaling (Krebs et al., 2002), possibly activating mTOR, which stimulates IRS-1 phosphorylation, and consequently reduces PI3-K activity (Kimball et al., 1999).

Moreover, this protein also reduces the inhibitory action of the tuberous sclerosis complex (TSC1/TSC2). The inhibition of this complex allows the activation of protein kinase Ras homologue-enriched in brain (Rheb), leading to $\mathrm{m}$ Tor phosphorylation and activation and consequently to phosphorylation and activation of S6K1 protein. The activation of this protein phosphorylates and activates ribossomal protein S6, favoring the synthesis of RNA, ribossomal proteins and elongation factors (Yang, Guan, 2007).

Leucine also exerts effects on the regulation of S6K1 protein, eukaryotic initiation factors (eIFs) and eukaryotic initiation factor $4 \mathrm{E}$ binding protein 1 (4E-BP1), which are involved in the initiation phase of protein synthesis, i.e. in protein translation (Kimball et al., 1999).

Leucine stimulates mTOR activity by phosphorylating and inhibiting 4E-BP1. Dissociation of 4E-BP1 complex promotes the formation of eukaryotic initiation factor 
4E (eIF4E), which is crucial to initiate the translation process. Moreover, leucine stimulates a second initiation factor-4G (eIF4G) through the mTor-independent pathway. The association of these two factors, eIF4E and eIF4G, forms a ribossomal complex eIF4F, which regulates translation initiation (Donato et al., 2007; Stipanuk, 2007).

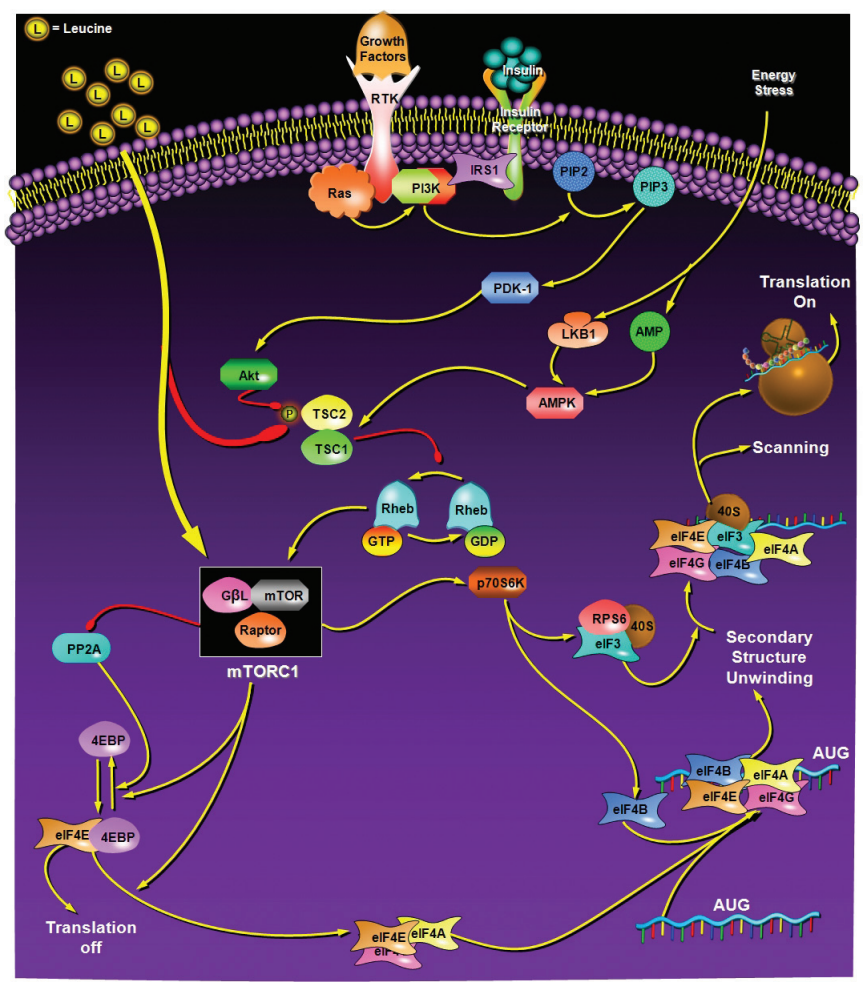

FIGURE 2 - Regulation of mTOR pathway by insulin and leucine. Adapted from Hinault et al. (2006).

Therefore, leucine also stimulates the synthesis of complexes that are responsible for protein translation process and consequently enhances cellular ability for protein synthesis (Kimball et al., 1999; Donato et al., 2007).

\section{EXPERIMENTAL STUDIES}

The molecular mechanisms involved in stimulating protein synthesis by leucine were evaluated in human studies. Studies evidenced that intravenous leucine infusion at high doses ( 3 to $7 \mathrm{~g}$ ) resulted in anabolic changes in protein turnover and nitrogen balance (Platell et al., 2000; Matthews, 2005). Additionally, it was observed that leucine stimulates protein synthesis during catabolic conditions induced by acute food restriction or by exhaustive exercise (Donato et al., 2007; Biolo et al., 1997).

It was also evidenced that, after overnight fasting or intense exercise, protein synthesis was reduced compared to the rate of protein degradation in muscle. This catabolic period persisted until adequate amounts of protein, specifically leucine, are consumed in order to increase the plasma and intracellular concentrations of this aminoacid (Phillips, 2004). Layman and Walker (2006) emphasized that the regulatory role of leucine is more important during catabolic periods such as fasting or low-calorie diets aiming to promote body weight loss, when plasma and intracellular concentrations of this aminoacid are low.

Although the effect of acute leucine supplementation in stimulating the anabolic process of protein synthesis has been verified, few studies have evaluated the efficiency of long-term leucine supplementation. Lynch et al. (2001) verified the effect of 12-day leucine or norleucine supplementation, on protein synthesis in rats. These authors observed that leucine and norleucine increased the rate of protein synthesis in adipose tissue, gastrocnemius muscle and in the liver, suggesting that leucine is able to stimulate protein synthesis through insulin-independent mechanisms.

In a study conducted by Donato et al. (2006), the effect of chronic leucine supplementation on body composition and indicators of protein nutritional status was evaluated in Wistar rats submitted to $50 \%$ food restriction for six weeks. In this experiment, maintenance of lean body mass and body protein content in the supplemented animals was not confirmed. However, lower body fat compared to non-supplemented animals was observed. This study also showed higher concentration of hepatic protein and RNA in the gastrocnemius muscle of the supplemented group. These results indicated that leucine supplementation in rats submitted to food restriction stimulated body fat loss, improved hepatic protein status and protein synthesis ability in muscle.

The authors did not consider the findings related to body composition striking, considering that some human studies have already evidenced that an increase in BCAA consumption can improve the body loss process (Layman et al., 2003a., Mourier et al., 1997; Layman, 2003; Layman et al., 2003b). Furthermore, studies comparing diets with different protein concentrations demonstrated significant changes in body composition in groups on a high-protein diet, especially by reducing fat mass and lowering loss of lean body mass. These changes were partially attributed to increased BCAA consumption, particularly leucine (Layman et al., 2003b; Farnsworth et al., 2003; Westerterp-Plantenga et al., 2004).

A study using Wistar rats submitted to 3 cycles of food restriction and refeeding ( 1 week of $50 \%$ food restriction, followed by 2 -weeks on ad libitum diet, per cycle), with or without chronic L-leucine plus L-phenylalanine supplementation, demonstrated a significant increase in 
lean body mass and body protein content in the supplemented group compared to the rats submitted to the same protocol without supplementation (Donato et al., 2007).

In a study aiming to investigate the possible mechanisms by which leucine stimulates protein synthesis, Anthony et al. (2000) evaluated protein synthesis in the skeletal muscle of animals submitted to food restriction for 18 hours, and in animals with free access to food. Supplementation with leucine, carbohydrate or leucine plus carbohydrate was orally administered to these groups. The authors verified that protein synthesis was restored similarly in both groups with leucine supplementation or without restriction. This effect was due to 4E-BP1 phosphorylation and formation of complex eIF4E-eIF4G. The results suggested that leucine had stimulated protein synthesis in the skeletal muscle possibly by activating the mTor signaling pathway, which promoted an increase in eIF4F formation.

O'Connor et al. (2003) observed that aminoacid infusion was able to increase protein synthesis in the skeletal muscle of neonate pigs. This effect was mediated by translation eIF activation. Escobar et al. (2006) reported that a physiological increase in plasma leucine levels, but not in isoleucine and valine, allowed this aminoacid to act as a nutrient signal to stimulate protein synthesis in skeletal and cardiac muscle of neonate pigs, increasing the availability of translation eIF, more specifically eIF4E, which is necessary to form the eIF4F complex.

Recently, Ventrucci, Mello and Gomes-Marcondes (2007) verified that leucine supplementation in pregnant rats with cancer prevented reduction in plasma insulin levels and increased protein kinase S6K1 and translation eIF expression. Based on these results, the authors suggested that a high-leucine diet increases protein synthesis in skeletal muscle of pregnant rats with tumor, possibly by activating eIF factors and/or the S6K1 pathway, thus emphasizing the role of leucine in the protein translation process.

\section{FINAL CONSIDERATIONS}

In summary, this review demonstrated that leucine regulates gene expression through multiple mechanisms including modulation of mTor activation, formation of the eIF4F complex, and phosphorylation of S6K1, consequently favoring protein synthesis.

Moreover, some studies have indicated that the anabolic effect of leucine is more evident in catabolic situations when leucine plasma and intracellular concentrations are low.

Leucine also exerts a notable effect on protein tur- nover and is able to promote catabolism of aminoacids, such as valine and isoleucine. This effect involves indirect downregulation of an enzyme responsible for their catabolism, resulting in reduced body aminoacids levels.

\section{ACKNOWLEDGEMENTS}

This work was supported by the São Paulo State Research Foundation (Fapesp), Grants 07/51964-9, $07 / 56230-3 ; 07 / 59291-3$. The authors would like to thank the Coordination for the Improvement of Higher Education Personnel (CAPES), the National Council for Scientific and Technological Development (CNPq) for their grants, and Ajinomoto for providing material for our research.

\section{REFERENCES}

ANTHONY, J. C.; ANTHONY, T. G.; KIMBALL, S. R.; VARY, T. C.; JEFFERSON, L. S. Orally administered leucine stimulates protein synthesis in skeletal muscle of postabsorptive rats in association with increased eIF4F formation. J. Nutr., v.130, p.139-145, 2000.

ANTHONY, J. C.; ANTHONY, T. G.; KIMBALL, S. R.; JEFFERSON, L. S. Oral administration of leucine stimulates ribosomal protein mRNA translation but not global rates of protein synthesis in the liver of rats. J. Nutr., v.131, p.1171-1176, 2001.

ARAUJO, Jr. J.; FALAVIGNA, G.; ROGERO, M. M.; PIRES, I. S. O.; PEDROSA, R. G.; CASTRO, I. A.; TIRAPEGUI, J. Effect of chronic supplementation with branched-chain amino acids on the performance and hepatic and muscle glycogen content in trained rats. Life Sci., v.79, p.13431348, 2006.

ASNAGHI, L.; BRUNO, P.; PRIULLA, M.; NICOLIN, A. mTOR: a protein kinase switching between life and death. Pharmacol. Res., v.50, p.545-549, 2004.

BAUM, J. I.; O'CONNER, J. C.; SEYLER, J. E.; ANTHONY, T. G.; FREUND, G. G.; LAYMAN, D. K. Leucine effects on PI3-kinase and insulin signaling in rat skeletal muscle. Am. J. Physiol., v.88, p.86-91, 2005.

BIOLO, G.; TIPTON, K. D.; KLEIN, S.; WOLFE, R. R. An abundant supply of amino acids enhances the metabolic effect of exercise on muscle protein synthesis. Am. $J$. Physiol., v.273, p.122-129, 1997. 
BOLSTER, D. R.; KIMBALL, S. R.; JEFFERSON, L. S. Translation control mechanisms modulate skeletal muscle gene expression during hypertrophy. Exerc. Sport. Sci. Rev., v.31, p.111-116, 2003.

BRUHAT, A.; AVEROUS, J.; CARRARO, V.; ZHONG, C.; REIMOLD, A. M.; KILBERG, M. S., AFOURNOUX, P. Differences in the molecular mechanisms involved in the transcriptional activation of the CHOP and asparagines synthetase genes in response to amino acid deprivation or activation of the unfolded protein response. J. Biol. Chem., v.277, p.48107-18414, 2002.

CAMPOS, P. L.; LUZ, S. S.; RIBEIRO, S. M. L.; TIRAPEGUI, J.; LANCHA Jr., A. H. Importância dos aminoácidos de cadeia ramificada: considerações sobre o metabolismo de proteínas e energia. Rev. Bras. Nutr. Clin., v.14, p.18-30, 1999.

COTA, D.; PROULX, K.; SMITH, K. A. B.; KOZMA, S. C.; THOMAS, G.; WOODS, S. C.;SEELEY, R. L. Hypothalamic mTOR signaling regulates food intake. Science, v.312, p.927-930, 2006.

CROZIER, S. J.; KIMBALL, S. R.; EMMERT, S. W.; ANTHONY, J. C.; JEFFERSON, L. S. Oral leucine administration stimulates protein synthesis in rat skeletal muscle. J. Nutr., v.13593, p.376-382, 2005.

DONATO, J. J.; PEDROSA, R. G.; TIRAPEGUI, J. Conseqüências da avaliação do peso corporal e da suplementação de L-leucina e L-fenilalanina na composição corporal e em parâmetros metabólicos em ratos. Rev. Bras. Cienc. Farm., v.40, p.124-127, 2004.

DONATO, J. J.; PEDROSA, R. G.; CRUZAT, V. F.; PIRES, I. S. O.; TIRAPEGUI, J. Effects of leucine supplementation on the body composition and protein status of rats submitted to food restriction. Nutrition., v.22, p.520-527, 2006.

DONATO, J. J.; PEDROSA, R. G.; ARAÚJO, J. A. J.; PIRES, I. S. O.; TIRAPEGUI, J. Effects of leucine and phenylalanine supplementation during intermittent periods of food restriction and refeeding in adults rats. Life Sci., v.81, p.31-39, 2007.

ESCOBAR, J.; FRANK, J. V. W.; SURVAWAN, A.; NGUVEN, H. V.; KIMBALL, S. R.; JEFFERSON, L. S.; DAVIS, T. A. Regulation of cardiac and skeletal muscle protein synthesis by individual branched-chain amino acid in neonatal pigs. Am. J. Physiol. Endocrinol. Metab., v.290, p.612-621, 2006.
FARNSWORTH, E.; LUSCOMBE, N. D.; NOAKES, M.; WITTERT, G.; ARGYIOU, E.; CLIFTON, P. M. Effect of a high-protein, energy-restricted diet on body composition, glycemic control, and lipid concentrations in overweight and obese hyperinsulinemic men and women. Am. J. Clin. Nutr., v.78, p.31-39, 2003.

FINGAR, D. C.; BLENIS, J. Target of rapamycin TOR: an integrator of nutrient and growth factor signals and coordinator of cell growth and cell cycle progression. Ontogeny, v.23, p.3151-3171, 2004.

GARLICK, P. J. The role of leucine in the regulation of protein metabolism. J. Nutr., v.135, p.1553S-1556S, 2005.

GEORGAKIS, G. V.; YOUNES, A. From rapa nu rapamicina: targeting PI3K/Akt/mTOR for cancer therapy. Expert. Rev. Anticancer Ther., v.6, p.131-140, 2006.

GUAL, P.; LE MARCHND-BRUSTEL, Y.; TANTI, J. F. Positive and negative regulation of insulin signaling through IRS-1 phosphorylation. Biochimie, v.87, p.99-109, 2005.

HAY, N.; SONENBERG, N. Upstream and downstream of mTOR. Genes. Dev., v.18, p.1926-1945, 2004.

HARRIS, R. A.; PAXTON, R.; POWELL, S. M.; GOODWIN, G. W.; KUNTZ, M. J.; HAN, A. C. Regulation of branchedchain alpha-ketoacid dehydrogenase complex by covalent modification. Adv. Enzyme. Regul., v.25, p.219-237, 1986.

HINAULT, C.; VAN OBBERGHEN, E.; MOTHE-SATNEY, I. Role of amino acids in insulin signaling in adipocytes and their potential to decrease insulin resistance of adipose tissue. J. Nutr. Biochem., v.17, p.374-378, 2006.

KATSANOS, C. S.; KOBAYASHI, H.; SHEFFIELD-MOORE, M.; AARSLAND, A.; WOLFE, R. R. A high proportion of leucine is required for optimal stimulation of the rate of muscle protein synthesis by essential amino acids in the elderly. Am. J. Physiol. Endocrinol. Met., v.291, p.381$387,2006$.

KIM, Y. B.; NIKOULINA, S. E.; CIARALDI, T. P.; HENRY, R. R.; KAHN, B. B. Normal insulin-dependent activation of Akt/protein kinase B, with diminished activation of phosphoinositide 3-kinase, in muscle in type 2 diabetes. $J$. Clin. Invest., v.104, p.733-741, 1999. 
KIMBALL, S. R.; SHANTZ, L. M.; HORETSKY, R. L.; JEFFERSON, L. S. Leucine regulates translation of specific mRNAs in L6 myoblasts through mTOR-mediated changes in availability of eIF4E and phosphorylation of ribosomal protein S6. J. Biol. Chem., v.274, p.11647-11652, 1999.

KIMBALL, S. R.; JEFFERSON, L. S. Signaling pathways and molecular mechanisms through which branchedchain amino acids mediate translational control of protein synthesis. J. Nutr., v.136, p.227-231, 2006.

KREBS, M.; KRSSAK, M.; BERNROIDER, E.;ANDERWALD, C.; BREHM, A.; MEYERSPEER, M.; NOWOTNY, P.; ROTH, E.; WALDHÄUSL, W.; RODEN,M. Mechanism of amino acid-induced skeletal muscle insulin resistance in humans. Diabetes, v.51, p.599-605, 2002.

LAYMAN, D. K. The role of leucine in weight loss diets and glucose homeostasis. J. Nutr., v.133, p.261-267, 2003.

LAYMAN, D. K.; SHIUE, H.; SATHER, C.; ERICKSON, D. J.; BAUM, J. Increased dietary protein modifies glucose and insulin homeostasis in adult women during weight loss. $J$. Nutr., v.133, p.405-410, 2003a.

LAYMAN, D. K.; BOILEAU, R. A.; ERICKSON, D. J.; PAINTER, J. E.; SHIUE, H.; SATHER, C.; CHRISTOU, D. D. A reduced ratio of dietary carbohydrate to protein improves body composition and blood lipid profiles during weight loss in adult women. J. Nutr., v.133, p.411-417, $2003 b$.

LAYMAN, K. L.; WALKER, D. A. Potential importance of leucine in treatment of obesity and the metabolic syndrome. J. Nutr., v. 136, p.319s-323s, 2006.

LYNCH, C. J.; FOX, H. L.; VARY, T. C.; JEFFERSON, L. S.; KIMBALL, S. R. Regulation of amino acid-sensitive TOR signaling by leucine analogues in adipocytes. J. Cell. Biochem., v.77, p.234-251, 2000.

LYNCH, C. J.; HUTSON, S. M.; PATSON, B. J. Tissuespecific effects of chronic dietary leucine and norleucine supplementation on protein synthesis in rats. Am. J. Physiol. Endocrinol. Metab., v.283, p.824-835, 2002a.

LYNCH, C. J.; PATSON, B. J.; ANTHONY, J.; VAVAL, A.; JEFFERSON, L. S.; VARY, T. C. Leucine is a direct-acting nutrient signal that regulates protein synthesis in adipose tissue. Am. J. Physiol. Endocrinol. Metab., v.283, p.503$153,2002 b$.
MALONEY, C. A.; REES, W. D. Gene-nutrient interactions during fetal development. Reproduction, v.130, p.401-410, 2005.

MATTHEWS, D. E. Observations of branched-chain amino acid administration in humans. J. Nutr., v.135, p.15801584, 2005.

MOURIER, A.; BIGARD, A. X.; KERVILER, E.; ROGER, B.; LEGRAND, H.; GUEZENNEC, C. Y. Combined effects of caloric restriction and branchedchain amino acid supplementation on body composition and exercise performance in elite wrestlers. Int. J. Sports. Med., v.18, p.47-55, 1997.

O'CONNOR, P. M. J.; KIMBALL, S. R.; SURYAWAN, A.; BUSH, J. A.; NGUYEN, H. V.; JEFFERSON, L. S.; DAVIS, T. A. Regulation of translation initiation by insulin and amino acids in skeletal muscle of neonatal pigs. Am. $J$. Physiol. Endocrinol. Metab., v.258, p.E40-E53, 2003.

PHILLIPS, S. M. Protein requirements and supplementation in strength sports. Nutrition, v.20, p.689-695, 2004.

PLATELL, C.; KONG, S. E.; MCCAULEY, R.; HALL, J. C. Branched-chain amino acids. J. Gastroenterol. Hepatol., v. 15, p.706-717, 2000.

PROUD, C. G. Regulation of mammalian translation factors by nutrients. Eur. J. Biochem., v.269, p.5338-5349, 2002.

ROGERO, M. M.; TIRAPEGUI, J. Aspectos atuais sobre aminoácidos de cadeia ramificada e exercício físico. Rev. Bras. Cien. Farm., v.44, p.536-575, 2008

ROSSI, L.; TIRAPEGUI, J. Aminoácidos de cadeia ramificada e atividade física. In: TIRAPEGUI, J. Nutrição, metabolismo e suplementação na atividade física. São Paulo: Editora Atheneu, 2005. p.153-161.

SHIMOMURA, Y.; MURAKAMI, T.; NAGASAKI, M.; HONDA, T.; GOTO, H.; KOTAKE, K.;KUROKAWA, T.; NONAMI, T. Regulation of branched-chain amino acid metabolism and pharmacological effects of branched-chain amino acids. Hepatol. Res., v.30, p.3-8, 2004.

SHIMOMURA, Y.; HARRIS, R. A. Metabolism and physiological function of branched-chain amino acids: discussion of session 1.J. Nutr., v.136, p.232S-233S, 2006. 
SMITH, C.; MARKS, A.; LIBERMAN, M. Mark's Basic Medical Biochemistry - A Clinical approach. (2.ed.) Baltimore: Lippincott Williams \& Wilkins, 2005. p.712730 .

STIPANUK, M. H. Leucine and protein synthesis: mTOR and Beyond. Nut. Rev., v.65, p.122-129, 2007.

VENTRUCCI, G.; MELLO, M.A. R.; GOMES-MARCONDES, M. C. C. Leucine-rich diet alters the eukaryotic translation initiation factors expression in skeletal muscle of tumourbearing rats. Bio. Med. Central. Cancer, v.7, p.42-46, 2007.
WESTERTERP-PLANTENGA, M. S.; LEJEUNE, M. P.; NIJS, I.; OOIJEN, M.; KOVACS, E. M. High protein intake sustains weight maintenance after body weight loss in humans. Int. J. Obes. Relat. Metab. Disord., v.281, p.5764, 2004.

ZICK, Y. Uncoupling insulin signalling by serine/threonine phosphorylation: a molecular basis for insulin resistance. Biochem. Soc. Trans., v.32, p.812-816, 2004.

YANG, O.; GUAN, K. L. Expanding mTOR signaling. Cell Res., v.17, p.666-681, 2007.

Received for publication on $05^{\text {th }}$ november 2008 Accepted for publication on $25^{\text {th }}$ june 2009 